\title{
Clinical findings and molecular cytogenetic characterization of 19q13.42 microduplication: three cases report and literature review
}

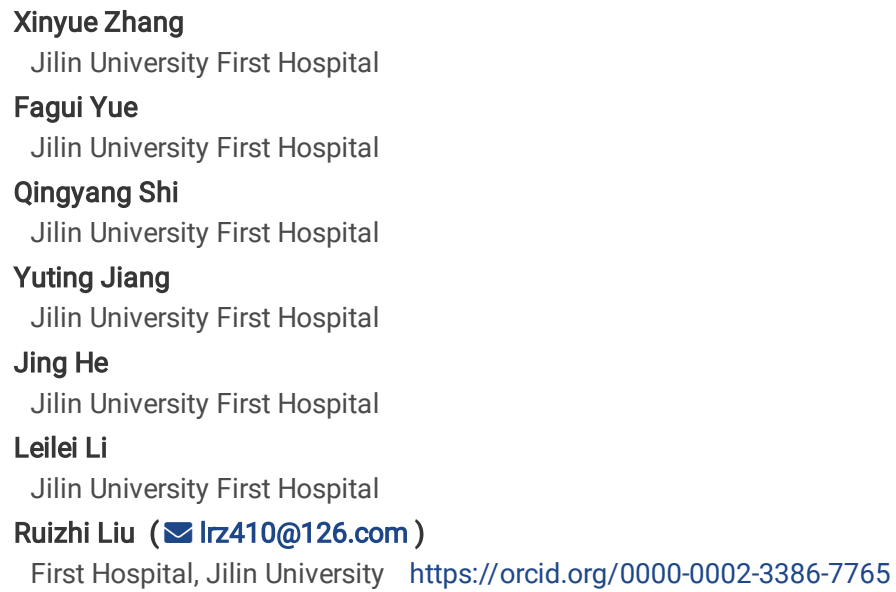




\section{Abstract}

Background

Trisomy $19 q$ is a recognizable syndrome and associated with a wide spectrum of clinical phenotypes in clinic. The purpose of this study was to explore the prenatal phenotypes of 19q13.42 duplication, which was rarely reported in clinic.

\section{Case presentation}

Three pregnant women presenting diverse indications for prenatal diagnosis accepted amniocentesis: increased nuchal translucency (case 2) and high risk of trisomy 21 (case 1 and case 3). Case 1 and case 2 shared similar duplicated locus in the region of 19q13.42, encompassing part NLRP12 gene. Case 2 inherited the chromosomal duplication from the mother with normal phenotypes. Case 3 carried a 1.445Mb duplication in the 19q13.42q13.43 region. It was proposed that evolutionary duplication of NLRP12 gene could have a causative role in autoinflammatory diseases development. The genotype-phenotype correlation depends mainly on the duplicated size and functional genes involved, which is still yet to be determined. All pregnant women chose to continue the pregnancy and delivered healthy children with no apparent abnormalities.

\section{Conclusions}

The 19q13.42 microduplications in our study are the smallest fragments compared to previous literature. We delineated 19q duplication cases without structural ultrasound anomalies for the first time, which enriched the prenatal phenotypes of this chromosomal aberration. It was proposed that long term follow up analysis should be guaranteed till adulthood to determine whether there will be other emerging clinical symptoms and developmental-behavioral disorders for such carriers.

\section{Background}

Chromosomal duplications are regarded to have close association with mental/growth retardation and other genetic disorders. Trisomy $19 \mathrm{q}$, partial or entire duplication of long arm of chromosome 19, was a rare chromosomal anomaly which was first reported in 1976 [1]. Currently, the incidence rate was not clear in clinic. The clinical features of trisomy 19 described in previously reported patients were various and included growth retardation, developmental delay, intellectual disability, microcephaly, heart malformations, anomalies of the genito-urinary tract and/or the gastrointestinal system and seizures, which usually led to poor prognosis [2-5].

The formation mechanism of trisomy $19 \mathrm{q}$ could be due to the presence of a de novo duplication, parental balanced reciprocal translocation, pericentric inversion, or small supernumerary marker, which made it difficult to define a distinct genotype-phenotype correlation $[6,7]$.

For prenatal cases presenting normal karyotypes, chromosomal submicroscopic imbalances of clinic significance could be diagnosed in approximately $1 \%$ of structurally normal pregnancies and $6 \%$ with structural malformations. Most frequent copy number variants (CNVs) observed in fetuses without structural anomalies included 15q11.2, Xp22.3, Xp21.1, 16p11.2, 1q21.1, 17p12, 16p13.11 and 22q11.21 [8]. To our knowledge, the first case of dup(19q) detected by prenatal diagnosis was reported in 1997 [3]. Herein, we describe three prenatal cases involving 19q13.42 microduplications with no structural anomalies observed, which are the smallest fragments compared to previous cases of trisomy $19 \mathrm{q}$.

\section{Case Presentation}

\section{Participants and clinical data}

Three pregnant women underwent amniocentesis for cytogenetic and chromosomal microarray analysis (CMA) analysis due to various indications for prenatal diagnosis: increased nuchal translucency (case 2) and high risk of trisomy 21 (case 1 and case 3). All couples were nonconsanguineous and healthy. No family history of diabetes mellitus or congenital malformations were observed. All pregnant women denied any exposure to alcohol, teratogenic agents, irradiation, or infectious diseases during their pregnancies. This study protocol was approved by the Ethics Committee of the First Hospital of Jilin University (No.2019 - 299), and written informed consents were obtained from all couples for publication of this case report and accompanying images.

\section{Methods}

\section{Cytogenetic analysis}

Amniocentesis was performed for karyotyping analysis with informed consent. Cytogenetic studies were performed on metaphases collected from cultured aminotic fluid cells from three pregnant women. Routine chromosome analysis was performed on G-banding techniques at $300-400$ banding resolution prepared from the cultured amniotic fluid cells according to standard protocols. Twenty metaphases were analyzed for all samples. The International System for Human Cytogenetic Nomenclature (ISCN 2016) was used to describe the karyotype [9].

\section{Chromosomal microarray analysis}

Genomic DNA was isolated from $10 \mathrm{~mL}$ aminotic fluid cells from all three pregnant women. The CytoScan 750K array (Affymetrix, Santa Clara, CA, USA) was applied to detect the known and novel chromosomal CNVs across the entire genome following the manufacturer's protocols and our previous study[10]. The procedures included genomic DNA extraction, digestion and ligation, PCR amplification, PCR product purification, quantification and fragmentation, labeling, array hybridization, washing and scanning. The CNVs detected were totally assessed by comparing them with published literature and the public databases: 
(1) Database of Genomic Variants (DGV)(http://dgv.tcag.ca/dgv/app/home),(2)DECIPHER(http://decipher.sanger.ac.uk/), (3) ISCA https://www.iscaconsortium.org/), (4) ECARUCA(http://www.ecaruca.net) and (5) OMIM(http://www.ncbi.nlm.nih.gov/omim).

\section{Results}

In our report, three cases with pure interstitial 19q13.42q13.43 microduplications were identified by CMA. G-banding analysis showed that all fetuses showed normal karyotypes, but CMA successfully identified 19q microduplications in the locus between 19q13.42 and 19q13.43. The cytogenetic, CMA results, and clinical features for all three cases were listed in Table 1. Indications for prenatal diagnosis were as follows: increased nuchal translucency (case 2) and high risk of trisomy 21 (case 1 and case 3). No structural abnormalities were detected in ultrasound examination. Among the duplicated regions, case 1 and case 2 shared similar duplicated locus in 19q13.42, encompassing part NLRP12 gene. Only the parents of case 2 opted for CMA to determine the origin of the duplication. It turned out that the fetus inherited the 19q13.42 microduplication from the phenotypically normal mother. All women chose to continue their pregnancies and delivered healthy infants at term. We then carried out a follow-up on their postnatal health conditions, including congenital defects, developmental retardation, body stature, craniofacial dysmorphisms, and skeletal anomalies. All infants were in healthy conditions, and no apparent abnormalities were observed till now, but long term follow up investigation was still necessary.

\section{Discussion And Conclusions}

In our study, we described three rare prenatal cases with pure 19q microduplications involving 19q13.42, ranging from $147 \mathrm{~kb}$ to $1.445 \mathrm{Mb}$, which presented no structural abnormalities in sonographic examination. Case 2 was proved to get the 19q13.42 duplication from the healthy mother. To the best of our knowledge, just five cases with prenatally diagnosed trisomy 19q had been described before, and only one case was involved in 19q microduplication. Currently, there is a lack of prenatal manifestations about this chromosomal microscopic imbalance. In our study, all fetuses with various $19 q$ duplicated loci showed no structural anomalies in pregnancy, which were different from previous trisomy $19 q$ cases and enriched the clinic phenotypes of $19 q$ microduplication.

Trisomy 19q, could be regarded as a recognizable syndrome and associated with a wide spectrum of clinical phenotypes, including growth and psychomotor retardation, intellectual disability, low birth weight, microcephaly, short neck, heart malformations, skeletal anomalies, genitourinary anomalies, gastrointestinal defects, seizures and facial dysmorphisms (receding forehead, ptosis, hypertelorism,flat nasal bridge, small nose, short philtrum, down turned mouth, ear anomalies) $[4,11,12]$. Most trisomy $19 q$ cases also carry monosomy of another chromosome, which makes it difficult to establish a clear phenotype-genotype correlation. Till now, only 19q12-q13.2 duplication is recognized as an obesity-related syndrome with intellectual disability and minor facial findings [13].

Pure 19q duplications, as a rare chromosomal anomaly, can be usually discovered in live borns by molecular genetic technique [1].To better interpret 19q duplication, we made a summary on clinic data observed in postnatal and prenatal cases with pure 19q duplication according to literature review, as shown in Table $1[1-4,6,11,14-23]$. The age of these cases ranged from new born to 39 years. Most trisomy $19 q$ cases $(11 / 19)$ could be detectable by traditional cytogenetic analysis, with the remainder (8/19) with 19q microduplication identified through molecular cytogenetic techniques. All cases varied in size, ranging from $25 \mathrm{~kb}$ to $12.4 \mathrm{Mb}$, were associated with various loci in 19q. Among these duplications, 12/19 cases were de novo, 5/19 cases were parentally inherited, and 2/19 cases were not available. The incidence rate of clinical presentations were as follows: Craniofacial dysmorphism (10/19), development delay (7/19), psychomotor retardation (7/19), brain anomaly (5/19), cardiac malformation (4/19), anomalies of urinary tract (3/19), skeletal anomaly (3/19), obesity (2/19), language disorders (2/19). The deformities of the face and head were the most typical clinic manifestations: ears anomaly (8/19), macrocephaly or microcephaly (6/19), short neck (5/19), nose anomalies (4/19). In addition, some rare anomalies, such as bilateral pronator syndrome, systemic-onset juvenile idiopathic arthritis, Duane retraction syndrome type III and autism spectrum disorder, could also be observed in 19q duplication cases. Generally speaking, postnatal cases usually presented a variety of clinical features with high specificity characterized by growth/psychomotor retardation and craniofacial dysmorphism. It was noteworthy that only five cases were prenatally detected, presenting various degrees of fetal abnormalities $[3,4,11,21,22]$. However, our cases showed no fetal structural anomalies, which indicated that prenatal trisomy $19 q$ cases might exhibit normal or abnormal ultrasound findings. Although the infants (cases 1 to 3 ) are now in healthy state, long term follow up analysis is still necessary to confirm whether there will be other emerging clinical symptoms or developmental-behavioral disorders.

To elaborate diverse clinical phenotypes, we also made detailed comparisons of cases harboring 19q13.42 microduplication in DECIPHER and ISCA databases (Fig. 1). Six cases overlapping similar duplicated regions with cases 1 and 2 were recorded. The proportions of pathogenicity were as follows: likely pathogenic (1/6) and uncertain (5/6). The incidence rate of clinical features were as follows: Development delay (3/6), intelligent disability (3/6), and autism $(2 / 6)$. Seven cases involving similar duplication with case 3 were described in the databases. The clinic pathogenicity in this duplicated locus was uncertain. Only one patient nssv 13649225 presented failure to thrive, hemolytic anemia, short stature and spherocytosis, while no evident phenotypes were observed for other six cases. Generally speaking, more evidence should be accumulated to explore the pathogenicity of 19q13.42 microduplication.

Dosage-sensitive genes with genome alteration would result in phenotypic effects and be associated with human diseases, including heart disease, cancers, diabetes, neuropsychiatric disorders and others [24]. Morbid genes in the region of 19q13.42q13.43 duplication involved in our cases were listed in Table 2. According to the ClinGen database, there are no available evidences that support the triplosensitivity of these genes. Based upon the published literature and public databases, we delineated the potentially pathogenic genes according to their functions and implications to predict the postnatal health conditions for these cases in future.

All CNVs detected in our case 1 and case 2 shared similar 19q13.42 microduplication, encompassing part NLRP12 gene (OMIM 609648; chr19: 5416521854321990). NLRP12 gene, also known as RNO, PYPAF7, and Monarch-1, encodes the protein of NLRP superfamily, which is implicated in the activation of 
proinflammatory caspases and hyperproduction of interleukin-1 $\beta$ [25]. NLRP12 plays critical roles in the regulation of NF-kB signaling, inflammasome activation, dendritic cell migration, and transcription of MHC class I genes [26]. The mutations in NLRP12 have been associated with familial cold autoinflammatory syndrome-2 (FCAS2; OMIM 611762), which displays autosomal dominant inheritance. This syndrome can be induced after exposure to cold and characterized by skin urticaria, arthralgia, conjunctivitis, musculoskeletal symptoms, deafness, lymphadenopathy, and abdominal pain, most of which are accompanied by recurrent fever and serologic evidence of inflammation $[27,28]$. Till now, there are no related reports on NLRP12 duplication in clinic. However, Galozzi et al. [28] proposed that evolutionary duplication of this gene can have a causative role in autoinflammatory diseases development. Hence, we suggested that these two infants should be followed up regularly on growth and health conditions, especially for autoinflammatory diseases.

In addition, the CMA detected a 19q13.42q13.43 duplication for case 3 , containing 19 OMIM genes. This locus comprises several NLRP (Nucleotide-binding oligomeriztion domain, Leucine rich Repeat and Pyrin domain) family members. NLRP4 is mainly responsible for the inhibition of NF-KB signaling, negative regulation of RLR signaling, autophagy inhibition. NLRP5 is related to the regulation of caspase activation, apoptosis in injured neurons, and embryonic development. The functions of other members (NLRP8, $-9,-11,-13$ ) still need to be further investigated $[19,26]$. As is known, the zinc finger proteins (ZNFs) are the largest transcription factor family in human genome, which contain finger-like protrusions and play critical roles in physiological and pathophysiological mechanisms [29]. Previous research showed that duplications of zinc finger genes commonly occurred during the evolution [30]. The detected duplicated locus in case 3 included ZNF580, -444, -582, $-667,-71$. Research on the functions of these genes are rare. According to OMIM database, the variations in ZNF582 gene might be associated with intellectual disability, which has yet to be confirmed. ZNF580 is supposed to be involved in endothelial cell proliferation and migration. Enhancing expression of ZNF667 can inhibit the apoptosis via inhibiting Bax and Fas expression. And ZNF667 might be a new oncogene in human hepatocellular carcinoma as a new therapeutic target through enhancing BCL-2 and decreasing BAX expression. Till now, no evidence supported these genes had much relevance to our subject.

In our study, the young ages of our cases and the lacking of comparable individuals limit the assessment of growth and development in future. So long-term follow up analysis should be guaranteed till adulthood. In addition, phenotypic diversity, incomplete penetrance, and the inheritance might be associated with the clinic pathogenicity of $19 q$ microduplication to different degrees, which needs further evidence to illustrate.

In our study, we described three rare prenatal cases consisting of 19q microduplication, encompassing 19q13.42 locus. They presented no ultrasound structural anomalies, which enriched the phenotypic spectrums of $19 q$ duplication. It is believed that more trisomy $19 q$ cases with clinic manifestations and molecular genetic characterization would help to refine clear genotype-phenotype correlations. For prenatally detected $19 \mathrm{q}$ duplications, long term follow up should be guaranteed till adulthood to confirm whether there will be other clinical symptoms and developmental-behavioral disorders afterwards.

\section{Abbreviations}

Chromosomal microarray analysis=CMA, copy number variants=CNVs, DGV=Database of Genomic Variants, ISCN 2016=International System for Human Cytogenetic Nomenclature, NCBI=National Center for Biotechnology Information, OMIM=Online Mendelian Inheritance in Man

\section{Declarations}

\section{Acknowledgements}

We express our sincere gratitude to all the staff of the Genetics Laboratory and Andrology Laboratory for their excellent work.

\section{Funding}

This work was supported by the 10th Youth Foundation of the First Hospital of Jilin University (grant number: JDYY102019038), and the Finance Department Health Special Project of Jilin Province, China (grant number: JLSCZD2019-022).

\section{Availability of data and materials}

The data and material used or analysed during the current study are available from the corresponding author on reasonable request.

\section{Authors' contributions}

XZ wrote the first draft of the manuscript. FY and QS collected the data of all the fetuses and couples. YJ, JH and LL participated in analysis and interpretation of data. RL reviewed the manuscript and were involved in its critical revision before submission. All authors read and approved the final manuscript.

\section{Ethics approval and consent to participate}

This report was approved by the Ethics Committee of the First Hospital of Jilin University (No.2019-299).The patients provided written informed consent for participating in this study.

\section{Consent for publication}

Written informed consents were obtained from couples for publication of this manuscript.

\section{Competing interests}


The authors declare that they have no competing interest.

\section{References}

1. Palomares Bralo M, Delicado A, Lapunzina P, Velázquez Fragua R, Villa O, Angeles Mori M, et al. Direct tandem duplication in chromosome 19q characterized by array CGH. Eur J Med Genet. 2008;51(3):257-63.

2. Qorri M, Oei P, Dockery H, McGaughran J. A rare case of a de novo dup(19q) associated with a mild phenotype. J Med Genet. 2002;39(10):E61.

3. Cotter PD, McCurdy LD, Gershin IF, Babu A, Willner JP, Desnick RJ. Prenatal detection and molecular characterization of a de novo duplication of the distal long arm of chromosome 19. Am J Med Genet. 1997;71(3):325-8.

4. Rombout S, Sartenaer D, Parmentier B, Dugauquier C, Gillerot Y. A rare case of de novo distal 19q trisomy prenatally diagnosed. Prenat Diagn. 2004;24(10):822-7.

5. Resta N, De Cosmo L, Susca FC, Capodiferro D, Nardone AM, Pastorivo D, et al. De novo unbalanced translocation leading to monosomy 9p24.3p24.1 and trisomy 19q13.42q13.43 characterized by microarray-based comparative genomic hybridization in a child with partial cortical dysplasia and craniofacial dysmorphisms without trigonocephaly. Am J Med Genet A. 2013;161A(3):632-6.

6. Nacinovich R, Villa N, Broggi F, Tavaniello C, Bomba M, Conconi D, et al. 19q12q13.2 duplication syndrome: neuropsychiatric long-term follow-up of a new case and literature update. Neuropsychiatr Dis Treat. 2017;13:2545-2550.

7. Schluth-Bolard C, Till M, Rafat A, Labalme A, Le Lorc'h M, Banquart E, et al. Monosomy 19pter and trisomy 19q13-qter in two siblings arising from a maternal pericentric inversion: clinical data and molecular characterization. Eur J Med Genet. 2008;51(6):622-30.

8. Wapner RJ, Martin CL, Levy B, Ballif BC, Eng CM, Zachary JM, et al. Chromosomal microarray versus karyotyping for prenatal diagnosis. N Engl J Med. 2012;367(23):2175-84.

9. J. McGowan-Jordan, A. Simons, and M. Schmid, An International System for Human Cytogenomic Nomenclature, S. Karger, Ed., Karger, Basel, Switzerland, 2016.

10. Zhang H, Liu X, Geng D, Yue F, Jiang Y, Liu R, et al. Molecular cytogenetic characterization of a mosaic small supernumerary marker chromosome derived from chromosome $Y$ in an azoospermic male: A case report. Medicine. 2019;98(30):e16661.

11. Tercanli S, Hösli I, Berlinger A, Beyer R, Achermann J, Holzgreve W. Prenatal diagnosis of a partial trisomy 19q. Prenat Diagn. 2000;20(8):663-5.

12. Sauter SM, Böhm D, Bartels I, Burfeind P, Laccone FA, Neesen J, et al. Partial trisomy of distal 19q detected by quantitative real-time PCR and FISH in a girl with mild facial dysmorphism, hypotonia and developmental delay. Am J Med Genet A. 2007;143A(10):1091-9.

13. Nevado J, Mergener R, Palomares-Bralo M, Souza KR, Vallespín E, Mena R, et al. New microdeletion and microduplication syndromes: A comprehensive review. Genet Mol Biol. 2014;37(1 Suppl):210-9.

14. Quack B, Van Roy N, Verschraegen-Spae MR, Klein F. Interstitial deletion and ring chromosome derived from 19q. Proximal 19q trisomy phenotype. Ann Genet. 1992;35(4):241-4.

15. Bhat M, Morrison PJ, Getty A, McManus D, Tubman R, Nevin NC. First clinical case of small de novo duplication of 19q (13.3-13.4) confirmed by FISH. Am J Med Genet. 2000;91(3):201-3.

16. Zung A, Rienstein S, Rosensaft J, Aviram-Goldring A, Zadik Z. Proximal 19q trisomy: a new syndrome of morbid obesity and mental retardation. Horm Res. 2007;67(3):105-10.

17. Lugli L, Malacarne M, Cavani S, Pierluigi M, Ferrari F, Percesepe A. A 12.4 Mb direct duplication in 19q12-q13 in a boy with cardiac and CNS malformations and developmental delay. J Appl Genet. 2011;52(3):335-9.

18. Rim JH, Kim JA, Yoo J. A Novel 1.13 Mb Interstitial Duplication at 19q13.32 Causing Developmental Delay and Microcephaly in a Pediatric Patient: the First Asian Case Reports. Yonsei Med J. 2017;58(6):1241-1244.

19. Tadaki H, Saitsu H, Nishimura-Tadaki A, Imagawa T, Kikuchi M, Hara R, et al. De novo 19q13.42 duplications involving NLRP gene cluster in a patient with systemic-onset juvenile idiopathic arthritis. J Hum Genet. 2011;56(5):343-7.

20. Abu-Amero KK, Kondkar AA, Al Otaibi A, Alorainy IA, Khan AO, Hellani AM, et al. Partial duplication of chromosome 19 associated with syndromic duane retraction syndrome. Ophthalmic Genet. 2015;36(1):14-20.

21. Babić I, Brajenović-Milić B, Petrović O, Mustać E, Kapović M. Prenatal diagnosis of complete trisomy 19q. Prenat Diagn. 2007;27(7):644-7.

22. Petre G, Lorès P, Sartelet H, Truffot A, Poreau B, Brandeis S, et al. Genomic duplication in the 19q13.42 imprinted region identified as a new genetic cause of intrauterine growth restriction. Clin Genet. 2018;94(6):575-580.

23. Pinto D, Pagnamenta AT, Klei L, Anney R, Merico D, Regan R, et al. Functional impact of global rare copy number variation in autism spectrum disorders. Nature. 2010;466(7304):368-72.

24. Rice AM, McLysaght A. Dosage-sensitive genes in evolution and disease. BMC Biol. 2017;15(1):78.

25. Kostik MM, Suspitsin EN, Guseva MN, Levina AS, Kazantseva AY, Sokolenko AP, et al. Multigene sequencing reveals heterogeneity of NLRP12-related autoinflammatory disorders. Rheumatol Int. 2018;38(5):887-893.

26. Tuncer S, Fiorillo MT, Sorrentino R. The multifaceted nature of NLRP12. J Leukoc Biol. 2014 Dec;96(6):991-1000.

27. Hull KM, Shoham N, Chae JJ, Aksentijevich I, Kastner DL. The expanding spectrum of systemic autoinflammatory disorders and their rheumatic manifestations. Curr Opin Rheumatol. 2003;15(1):61-9.

28. Galozzi P, Punzi L, Sfriso P. Clinical Overlapping in Autoinflammatory Diseases: The Role of Gene Duplication. Front Immunol. $2017 ; 8: 392$. 
29. Squassina A, Meloni A, Chillotti C, Pisanu C. Zinc finger proteins in psychiatric disorders and response to psychotropic medications. Psychiatr Genet. 2019;29(5):132-141.

30. Looman C, Abrink M, Mark C, Hellman L. KRAB zinc finger proteins: an analysis of the molecular mechanisms governing their increase in numbers and complexity during evolution. Mol Biol Evol. 2002;19(12):2118-30

\section{Tables}

Table 1. Clinical features of previously prenatal and postnatal cases with pure 19q duplication 


\begin{tabular}{|c|c|c|c|c|c|c|c|c|}
\hline References & $\begin{array}{l}\text { Quack } \\
\text { et al.[14] }\end{array}$ & $\begin{array}{l}\text { Bhat } \\
\text { et al.[15] }\end{array}$ & $\begin{array}{l}\text { Qorri } \\
\text { et al.[2] }\end{array}$ & $\begin{array}{l}\text { Zung } \\
\text { et al.[16] }\end{array}$ & $\begin{array}{l}\text { Palomares et } \\
\text { al.[1] }\end{array}$ & $\begin{array}{l}\text { Lugli, } \\
\text { et al.[17] }\end{array}$ & Rim et al. [18] & $\begin{array}{l}\text { Nacinovich } \\
\text { al.[6] }\end{array}$ \\
\hline Age/sex & $2 y / M$ & $18 \mathrm{~m} / \mathrm{M}$ & $27 \mathrm{~m} / \mathrm{F}$ & $14 y / M$ & $15 \mathrm{~m} / \mathrm{F}$ & $3 y / M$ & $5 y / M$ & $10 y / M$ \\
\hline $\begin{array}{l}\text { Duplicated } \\
\text { region }\end{array}$ & $\begin{array}{l}19 q 11.05- \\
13.2\end{array}$ & $\begin{array}{l}19 q 13.3- \\
13.4\end{array}$ & $19 q 13.1-13.3$ & $19 q 12-13.2$ & $19 q 12-13.2$ & $19 q 12-13.2$ & $19 q 13.32$ & 19q12q13.: \\
\hline $\begin{array}{l}\text { Duplication } \\
\text { size(Mb) }\end{array}$ & N.A. & N.A. & N.A. & N.A. & $10.8 \mathrm{Mb}$ & $12.4 \mathrm{Mb}$ & $1.13 \mathrm{Mb}$ & 8.17 Mb \\
\hline Inheritance & Maternal & De novo & De novo & De novo & De novo & De novo & De novo & De novo \\
\hline Karyotype & $\begin{array}{l}47, X Y, r(19) \\
\text { (q11.05q13.2) }\end{array}$ & $\begin{array}{l}\text { 46,XY,dup(19) } \\
\text { (q13.3q13.4) }\end{array}$ & $\begin{array}{l}\text { 46,XX,dup(19) } \\
\text { (q13.1q13.3) }\end{array}$ & $\begin{array}{l}47, X Y,+\operatorname{der}(19) \\
\text { (q12q13.2) }\end{array}$ & $\begin{array}{l}46, X X, d u p(19) \\
\text { (q12q13.2) }\end{array}$ & $\begin{array}{l}\text { 46,XY,dup(19) } \\
\text { (q12q13.2) }\end{array}$ & $46, X Y$ & $\begin{array}{l}\text { 46,XY,dup(1) } \\
\text { (q12q13.2) }\end{array}$ \\
\hline $\begin{array}{l}\text { Chromosomal } \\
\text { microarray } \\
\text { results } \\
\text { (hg19) }\end{array}$ & N.A. & N.A. & N.A. & N.A. & $\begin{array}{l}\text { From } \\
36.95 \mathrm{Mb} \text { to } \\
47.75 \mathrm{Mb} \\
19 \mathrm{q} 12 \mathrm{q} 13.2\end{array}$ & $\begin{array}{l}\text { From } 32,964 \\
\mathrm{Mb}(19 q 12) \text { to } \\
45,391 \\
\mathrm{Mb}(19 q 13.2)\end{array}$ & $\begin{array}{l}\text { chr19:51839641- } \\
52967920\end{array}$ & $\begin{array}{l}19 q 12 q 13 .: \\
(28,740,63 t \\
36,906,767\end{array}$ \\
\hline $\begin{array}{l}\text { Development } \\
\text { delay }\end{array}$ & + & + & + & + & + & + & + & - \\
\hline $\begin{array}{l}\text { Psychomotor } \\
\text { retardation }\end{array}$ & + & N.A. & + & + & + & + & + & + \\
\hline $\begin{array}{l}\text { Craniofacial } \\
\text { dysmorphism }\end{array}$ & $\begin{array}{l}\text { Macrocephaly, } \\
\text { hypertelorism, } \\
\text { downslanting } \\
\text { palpebral } \\
\text { fissures, } \\
\text { prominent } \\
\text { nose, } \\
\text { large ears and } \\
\text { unusual } \\
\text { shaped } \\
\text { mouth. }\end{array}$ & $\begin{array}{l}\text { Microcephaly, } \\
\text { flat face, high } \\
\text { frontal } \\
\text { hairline, } \\
\text { hypertelorism, } \\
\text { epicanthic } \\
\text { folds, } \\
\text { convergent } \\
\text { strabismus, } \\
\text { long philtrum, } \\
\text { downturned } \\
\text { mouth, } \\
\text { micrognatia, } \\
\text { large ears, } \\
\text { short neck } \\
\text { with } \\
\text { redundant } \\
\text { skin folds. }\end{array}$ & - & $\begin{array}{l}\text { Macrocephaly, } \\
\text { round face, } \\
\text { upslanting } \\
\text { palpebral } \\
\text { fissures, thick } \\
\text { auricles. }\end{array}$ & $\begin{array}{l}\text { Microcephaly, } \\
\text { hypertelorism, } \\
\text { epicanthic } \\
\text { folds, } \\
\text { strabismus, } \\
\text { long philtrum, } \\
\text { downturned } \\
\text { mouth, large } \\
\text { ears, short } \\
\text { neck, } \\
\text { sparce hair. }\end{array}$ & $\begin{array}{l}\text { high forehead } \\
\text { midface, } \\
\text { trigonocephaly, } \\
\text { sparse } \\
\text { eyebrows, } \\
\text { convergent } \\
\text { strabismus, } \\
\text { bulbous nose, } \\
\text { long philtrum, , } \\
\text { high and } \\
\text { narrow palate, } \\
\text { short neck with } \\
\text { redundant skin } \\
\text { folds, } \\
\text { protruding ears }\end{array}$ & $\begin{array}{l}\text { Microcephaly, } \\
\text { broad nasal } \\
\text { bridge, high } \\
\text { forehead with } \\
\text { posterior hair- } \\
\text { line, and upward } \\
\text { directed corners } \\
\text { of the eyes }\end{array}$ & macroceph \\
\hline $\begin{array}{l}\text { Brain } \\
\text { anomaly }\end{array}$ & - & - & - & $\begin{array}{l}\text { Cortical } \\
\text { atrophy, } \\
\text { partial } \\
\text { agenesis of } \\
\text { corpus } \\
\text { callosum. }\end{array}$ & $\begin{array}{l}\text { Thinning of } \\
\text { corpus } \\
\text { callosum } \\
\text { and splenium. }\end{array}$ & $\begin{array}{l}\text { enlargement of } \\
\text { the frontal- } \\
\text { temporal } \\
\text { subarachnoid } \\
\text { spaces, partial } \\
\\
\text { agenesis of } \\
\text { the corpus } \\
\text { callosum, } \\
\text { dilation of the } \\
\text { lateral } \\
\text { ventricles, and } \\
\text { a large } \\
\text { cisterna } \\
\text { magna. }\end{array}$ & - & N.A. \\
\hline $\begin{array}{l}\text { Cardiac } \\
\text { malformation }\end{array}$ & - & $\begin{array}{l}\text { Ductus } \\
\text { arteriosus, } \\
\text { left } \\
\text { superior vena } \\
\text { cava. }\end{array}$ & - & - & - & $\begin{array}{l}\text { interatrial and } \\
\text { interventricular } \\
\text { defect }\end{array}$ & - & N.A. \\
\hline
\end{tabular}




\begin{tabular}{|c|c|c|c|c|c|c|c|c|}
\hline $\begin{array}{l}\text { Anomalies of } \\
\text { urinary tract }\end{array}$ & N.A. & N.A. & N.A. & N.A. & N.A. & N.A. & N.A. & N.A. \\
\hline Obesity & + & N.A. & - & + & - & - & - & - \\
\hline $\begin{array}{l}\text { Skeletal } \\
\text { anomaly }\end{array}$ & N.A. & N.A. & N.A. & N.A. & N.A. & N.A. & N.A. & N.A. \\
\hline Others & & $\begin{array}{l}\text { Left } \\
\text { stenc }\end{array}$ & & & Нурс & & & $\begin{array}{l}\text { Bilateral } \\
\text { pronator } \\
\text { syndrome } \\
\text { with valgus } \\
\text { knee. }\end{array}$ \\
\hline
\end{tabular}

Table 1. Clinical features of previously prenatal and postnatal cases with pure 19q duplication (Continued) 


\begin{tabular}{|c|c|c|c|c|c|c|c|}
\hline References & Cotter et al ${ }^{[3]}$ & Rombout et al ${ }^{[4]}$ & Tercanli et al ${ }^{[11]}$ & $\begin{array}{l}\text { Babic' et } \\
\text { al }^{[21]}\end{array}$ & Petre et al ${ }^{[22]}$ & Pinto et al ${ }^{[23]}$ & C \\
\hline Age/sex & TOP & TOP/F & TOP/M & TOP/M & TOP/N.A. & N.A. & 7 \\
\hline $\begin{array}{l}\text { Duplicated } \\
\text { region }\end{array}$ & $19 q 13.2 q 13.4$ & 19q13.3qter & 19q13.1qter & 19q11qter & $19 q 13.42$ & $19 q 13.42$ & 1 \\
\hline $\begin{array}{l}\text { Duplication } \\
\text { size(Mb) }\end{array}$ & N.A. & N.A. & N.A. & N.A. & $1.06 \mathrm{Mb}$ & $25 \mathrm{~kb}$ & 1 \\
\hline Inheritance & De novo & De novo & De novo & Maternal & Paternal & Maternal & $\Lambda$ \\
\hline Karyotype & $\begin{array}{l}\text { 46,XYdir } \\
\text { dup(19) } \\
\text { (q13.2;q13.4) }\end{array}$ & $\begin{array}{l}\text { 46,XX,der(22)t(19;22) } \\
\text { (q13.3;p13) }\end{array}$ & 46,XY,dup(19)(q13.1;qter) & $\begin{array}{l}46, X Y, \operatorname{der}(21) \\
(19 ; 21) \\
(\mathrm{q} 11 ; \mathrm{p} 13)\end{array}$ & N.A. & N.A. & 4 \\
\hline $\begin{array}{l}\text { Chromosomal } \\
\text { micro array } \\
\text { results } \\
\text { (hg19) }\end{array}$ & N.A. & N.A. & N.A. & N.A. & $\begin{array}{l}19 q 13.42(53759522- \\
54821015) \times 3\end{array}$ & $\begin{array}{l}19 q 13.42(55153092- \\
55178778) \times 3\end{array}$ & $\begin{array}{l}1 \\
5\end{array}$ \\
\hline $\begin{array}{l}\text { Development } \\
\text { delay }\end{array}$ & N.A. & N.A. & N.A. & N.A. & N.A. & N.A. & - \\
\hline $\begin{array}{l}\text { Psychomotor } \\
\text { retardation }\end{array}$ & N.A. & N.A. & N.A. & N.A. & N.A. & N.A. & - \\
\hline $\begin{array}{l}\text { Craniofacial } \\
\text { dysmorphism }\end{array}$ & - & $\begin{array}{l}\text { Short neck, } \\
\text { microretrognathia, } \\
\text { flat nose, low set } \\
\text { ears }\end{array}$ & N.A. & $\begin{array}{l}\text { Short neck } \\
\text { with } \\
\text { redundant } \\
\text { skin } \\
\text { folds, flat } \\
\text { nose, } \\
\text { low set ears }\end{array}$ & N.A. & - & 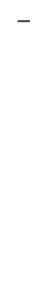 \\
\hline $\begin{array}{l}\text { Brain } \\
\text { anomaly }\end{array}$ & N.A. & $\begin{array}{l}\text { Dilatation of the } \\
\text { lateral ventricles }\end{array}$ & N.A. & $\begin{array}{l}\text { Moderate } \\
\text { dilatation of } \\
\text { the IV } \\
\text { ventricle }\end{array}$ & N.A. & - & - \\
\hline $\begin{array}{l}\text { Cardiac } \\
\text { malformation }\end{array}$ & N.A. & $\begin{array}{l}\text { VSD, atretic } \\
\text { pulmonary artery, } \\
\text { hypoplastic right } \\
\text { heart. }\end{array}$ & $\begin{array}{l}\text { VSD, aortic } \\
\text { coarctation,continuous } \\
\text { fusion of the left } \\
\text { pulmonary artery } \\
\text { with aortic arch, } \\
\text { absent right } \\
\text { pulmonary artery }\end{array}$ & N.A. & N.A. & N.A. & - \\
\hline $\begin{array}{l}\text { Anomalies of } \\
\text { urinary tract }\end{array}$ & N.A. & $\begin{array}{l}\text { Bilateral pyelo-calical } \\
\text { dilatation }\end{array}$ & $\begin{array}{l}\text { Cystic renal dysplasia, } \\
\text { renal fusion, } \\
\text { hydronephrosis, } \\
\text { bilateral absence of } \\
\text { ureters }\end{array}$ & $\begin{array}{l}\text { Pyelo-calical } \\
\text { dilatation on } \\
\text { the left } \\
\text { kidney, } \\
\text { stenosis at } \\
\text { the } \\
\text { vesicoureteric } \\
\text { junction, } \\
\text { horseshoe } \\
\text { kidney } \\
\text { dilated left } \\
\text { ureter }\end{array}$ & N.A. & N.A. & - \\
\hline Obesity & N.A. & N.A. & N.A. & N.A. & N.A. & N.A. & $\Lambda$ \\
\hline $\begin{array}{l}\text { Skeletal } \\
\text { anomaly }\end{array}$ & N.A. & $\begin{array}{l}\text { Bilateral } \\
\text { clinodactyly }\end{array}$ & Rocker bottom feet & N.A. & N.A. & N.A. & - \\
\hline Language & N.A. & N.A. & $\begin{array}{l}\text { N.A. } \\
\quad \text { Page } 9 / 11\end{array}$ & N.A. & N.A. & + & $\Lambda$ \\
\hline
\end{tabular}


disorders

\begin{tabular}{|c|c|c|c|c|c|}
\hline Others & $\begin{array}{l}\text { Cystic } \\
\text { hygroma }\end{array}$ & $\begin{array}{l}\text { Ultrasound findings: } \\
\text { abnormal nuchal } \\
\text { translucency }\end{array}$ & $\begin{array}{l}\text { Ultrasound findings: } \\
\text { nuchal oedema, } \\
\text { mild hydrops } \\
\text { fetalis with ascites, } \\
\text { oligohydramnion. Heart } \\
\text { Malformations,Anomalies } \\
\text { of } \\
\text { urinary tract }\end{array}$ & $\begin{array}{l}\text { Ultrasound } \\
\text { findings: } \\
\text { increased } \\
\text { nuchal fold, } \\
\text { absence of } \\
\text { fetal nasal } \\
\text { bone, } \\
\text { anomalies of } \\
\text { central } \\
\text { nervous } \\
\text { system and } \\
\text { urinary tract, } \\
\text { intracardial } \\
\text { calcifications }\end{array}$ & $\begin{array}{l}\text { Intrauterine growth ASD } \\
\text { restriction, } \\
\text { intrauterine fetal } \\
\text { death }\end{array}$ \\
\hline
\end{tabular}

F, female; M, male; m, months; y, years; +, present; -, not present; N.A., not available; DS, Down's syndrome; ASD, Autism Spectrum Disorder; VSD, ventricular septal defect; TOP, termination of pregnancy.

Table 2. Morbid genes in the region of 19q13.42q13.43 duplication involved in our cases.

\begin{tabular}{|c|c|c|c|}
\hline Gene & OMIM & Description & Disease \\
\hline NLRP12 & 609648 & NLR family pyrin domain containing 12 & Familial cold autoinflammatory syndrome 2 \\
\hline PRKCG & 176980 & protein kinase $\mathrm{C}$ gamma & Spinocerebellar ataxia 14 \\
\hline PRPF31 & 606419 & pre-mRNA processing factor 31 & Retinitis pigmentosa 11 \\
\hline CNOT3 & 604910 & CCR4-NOT transcription complex subunit 3 & $\begin{array}{l}\text { Intellectual developmental disorder with speech delay, autism, and } \\
\text { dysmorphic facies }\end{array}$ \\
\hline MBOAT7 & 606048 & $\begin{array}{l}\text { membrane bound 0-acyltransferase domain } \\
\text { containing } 7\end{array}$ & Mental retardation, autosomal recessive 57 \\
\hline TSEN34 & 608754 & tRNA splicing endonuclease subunit 34 & Pontocerebellar hypoplasia type $2 \mathrm{C}$ \\
\hline KIR3DL1 & 604946 & $\begin{array}{l}\text { killer cell immunoglobulin like receptor, three Ig } \\
\text { domains and long cytoplasmic tail } 1\end{array}$ & Human Immunodeficiency Virus Type 1, Susceptibility to \\
\hline NLRP7 & 609661 & NLR family pyrin domain containing 7 & Hydatidiform mole, recurrent, 1 \\
\hline GP6 & 605546 & glycoprotein VI platelet & Bleeding disorder, platelet-type, 11 \\
\hline TNNT1 & 191041 & troponin $\mathrm{T} 1$, slow skeletal type & Nemaline myopathy 5, Amish type \\
\hline TNNI3 & 191044 & troponin 13 , cardiac type & $\begin{array}{l}\text { Cardiomyopathy, familial restrictive, 1, Cardiomyopathy, dilated, 2A, } \\
\text { Cardiomyopathy, dilated, 1FF, Cardiomyopathy, hypertrophic, } 7\end{array}$ \\
\hline DNAAF3 & 614566 & dynein axonemal assembly factor 3 & Ciliary dyskinesia, primary, 2 \\
\hline
\end{tabular}

\section{Figures}




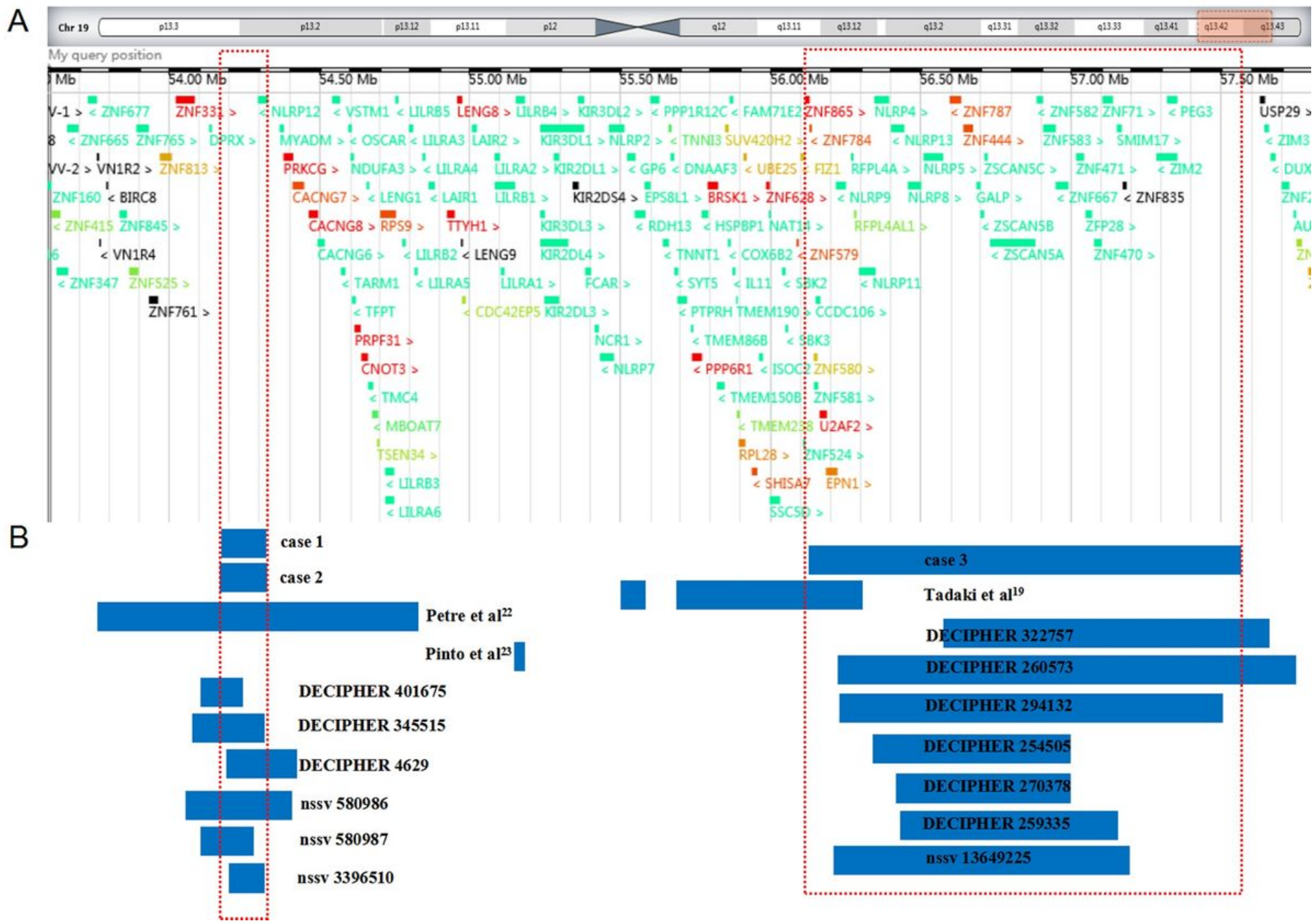

\section{Figure 1}

Scale representation of the duplicated region in the long arm of chromosome 19q13.42q13.43 (https://decipher.sanger.ac.uk/) (A) Location of genes in the region. (B) Microduplications detected in the present cases (cases 1 to 3 ) and previously reported microduplications involving 19q13.42q13.43 in the literature and public databases. 